\title{
20대 성인의 기능적 움직임 검사 점수의 성차
}

\author{
강희진 · 박우영 · 안근옥 \\ 단국대학교
}

\begin{abstract}
Hee-jin Kang · Woo-young Park · Keun-ok An Gender Differences in Functional Movement Screen in 20s Adults. KINESIOLOGY, 2015, 17(2): 1-9. [PURPOSE] The purpose of this study was to examine gender differences in the scores of FMS (Functional Movement Screen) in 20s adult. [METHODS] $83(50$ male and 33 female) individuals in 20s adults who do not exercise regularly with no recent( $<6$ months) history of muscular skeletal injury were recruited for the study. The Functional Movement Screen consisted of 7 tests (DS; deep squat, IL; in-line lunge, HS; hurdle step, ASLR; active straight leg raise, SM; shoulder mobility, PU; trunk stability push up, RS; rotary stability. Mann-Whitney $U$ tests were used to examine differences between male and female in the functional movement tests due to the rank-order nature of the data. [RESULTS] There was no statistically significant difference in total score between female(15.21 \pm 2.2$)$ and male(15.38 \pm 2.4$)$ while there was significant difference in SM, ASLR, PU between female and male. mean score of SM, ASLR, PU was $252 \pm 0.7,2.32 \pm 0.7,2.04 \pm 0.9$ in male. mean score of SM, ASLR, PU was $2.87 \pm 0.3,279 \pm 0.5,1.27 \pm 0.7$ in female. Female performed better on the SM, ASLR compared to male. The PU scores indicated that males were better than females in trunk stability. There was no significant difference in DS, IL, HS, and RS between females and males. [CONCLUSIONS] In conclusion, male and female of 20s adults may exhibit different qualities of functional movements. Therefore, strength and conditioning training program for sports injury prevention focused on improving functional movement in 20s adults should consider these gender differences.
\end{abstract}

Key words : functional movement screen, gender, sports injury 주요어 : 기능적 움직임 검사, 성차, 스포츠 손상

\section{서론}

운동손상의 예방을 위해서는 우선 그 원인을 밝혀 서 적절한 조치를 취함이 중요하다. 또한 가능한 운동 손상의 위험성도 미리 예측하여 이를 위한 컨디셔닝 (conditioning) 프로그램을 통하여 위험에 대처할 수 있어야 할 것이다.

성차도 운동손상의 한 원인으로 지목되고 있다. 일 찍이 무릎의 전방십자인대손상 연구에서 성차가 운동 손상의 하나의 원인으로 지목되었다(Chandy \& Grana, 1985). 그리고 전방십자인대 재건 술 후 재활 훈련 효 과에 따른 기능성 수행능력에 남녀 간에 성차에 대한 연구도 있었다(An et al., 2013).

손상부위에 대한 성차에 관한 연구는 아직 논란의 소 지가 많다. 운동선수들을 대상으로 한 선행연구에서 손 상부위가 남성과 여성 사이에 차이가 있었다(Lindenfeld et al., 1994; Messina et al., 1999)는 보고들이 있었다. 한편 운동손상 빈도의 성차에 대한 연구에서, 운동종목 에 따라 차이가 있을 수 있지만, 여성선수가 남성선수보 다 운동손상 빈도가 높았다는 연구들(Backous et al., 1988; Bell et al., 2000; Gwinn et al., 2000; Knapik et al., 2001; Myklebust et al., 1998; Zelisko et al., 1982)도 있는가 하면, 그렇지 않았다는 연구들(Stevenson et al., 2000; Beachy et al., 1997; Wiesler et al., 1996; Baumhauer et al., 1995)도 있어 논란이 계속되고 있다. 남녀 간에 하지 등에서 기능해부학적 차이가 큰 만큼 (Livingston \& Gahagan, 2001; Charlton et al., 2002; Hewett et al., 1999) 운동손상의 성차에 관한 연구는 다 양한 신체부위로 확대될 필요가 있다.

선수들에게 있어서 시즌 전 검사는 부상을 예방하 기 위해서, 스포츠 특성 기능 손실이 있는지 혹은 재 활을 실시해야 하는지에 대한 내용을 조언하기 위하

* 교신저자: golterea@hanmail.net 
여, 그리고 스포츠 수행능력을 향상시키기 위해서 실 시한다(Batt et al., 2004; Kibler et al., 1989; Mottram \& Comerford, 2008). 그러나 이러한 평가는 일반적인 운동에 기초한 개개인의 정보를 바탕으로 하고 있기 때문에 평가자체가 부상을 예방할 수 있다고 하는 것 은 부적절해 보인다(Batt et al., 2004; Kibler et al., 1989; Mottram \& Comerford, 2008)는 견해가 있다. 또한 최근에는 검사가 수행능력의 제한이나 더 부상 당할 가능성을 확인할 수 있는 근본적인 움직임 패턴 을 활용한 더 기능적인 접근으로 바뀌고 있다(Kiesel et al., 2007; Minick et al., 2010). 또한 많은 운동의학 전문가들은 움직임 손실을 증명하기 위해서 더 기능 적인 접근을 할 수 있는 특별한 평가 테크닉이 필요 하다(Cook et al., 1998)고 언급했다.

이러한 비평과 요구 속에서 Cook et al.(2006a, 2006b)은 기능적 움직임 검사(Functional Movement Screen, FMS)를 개발한바 있다. 이 검사는 근력, 유연 성, 가동범위(ROM), 협응력, 평형성 그리고 고유수용 감각을 동시에 평가 할 수 있도록 한 평가시스템으로 서, 운동손상의 가능성을 사전에 검토할 수 있는 검사 도구라는 사실이 확인되었고(Kisel et al., 2007; Lisman et al., 2013) 여러 연구자들에게 의해서 타당도와 신 뢰도가 검증되었다(Anstee et al., 2003; Hickey et al., 2010; Minick et al., 2010; Onate et al., 2012; Parenteau-G et al., 2014; An \& Lee, 2010).

FMS 점수는 7 가지 근본적인 움직임 패턴에서 각각 0 에서 3점의 점수를 받을 수 있다. 보상작용 없이 정 상적인 움직임에서는 각각 3점씩의 점수를 받기 때문 에 FMS 점수의 만점은 21점이다. 선행연구에 의하면 FMS 점수가 14점 이하일 경우 손상의 위험이 높아진 다(Kiesel et al., 2007; Kiesel et al., 2008; Lisman et al., 2013)고 보고되고 있다.

한편 FMS 점수의 성차에 관한 한 연구(Butler et al., 2009)가 있었다. 그러나 이 연구는 대상자가 중학 생으로서 성장기에 있었던바 성장이라는 요인이 배제 되지 않았고, 대상자의 수가 32명(남 19, 여 13)으로서 남녀의 성차를 밝히기에는 너무나 적은 피검자 수였 다. 또한 이러한 FMS 관련 연구들은 운동선수 및 활 동적인 대상자들을 대상으로 한 연구이며, 규칙적인 운동을 하지 않는 일반 성인들을 대상으로 한 연구는
찾아보기 힘들다. 그러므로 FMS 점수를 통하여 20대 남녀 사이에 기능적 움직임의 성차를 밝히는 것은 운 동학적 그리고 운동의과학적 의미가 크다고 본다.

최근 운동선수뿐만 아니라 수많은 사람들이 운동이 나 운동경기에 참여하고 있으므로 그만큼 부상의 사 례가 늘고 있다. 특히 20대의 경우 성장이 멈추고 노 화가 진행되기 시작하는 시점전의 연령으로서(Kim et al., 2007) 해부기능학적 성차 이외의 변수를 최소화시 킬 수 있는 최적의 연령대라 사료된다.

그러므로 이 연구는 FMS 점수를 통하여 20대 남 녀의 기능적 움직임의 질적 차이를 규명하고자 한다.

이 같은 연구는 기능적 움직임 능력이 떨어지면 손 상 가능성을 높인다는 연구결과(Cook et al., 1998; Kiesel et al., 2007; Minick et al., 2010)를 전제로 20 대에서부터 운동손상의 위험성에 성차가 존재하는지 를 예측하는데 도움을 줄 수 있을 것으로 기대된다.

\section{연구 방법}

\section{연구대상}

이 연구의 대상자는 6 개월 이내에 부상을 당한 경 험이 없는 20대 성인을 대상으로 하였다. 또한 규칙적 인 운동을 하고 있지 않은 대상자를 선정하였으며, 일 차적으로 이 연구에 대한 자세한 설명과 함께 대상자 들의 동의를 얻은 후 검사를 실시하였다. 이 연구를 위한 대상자는 총 83 명(남자 50명, 여자 33명)이며, 대 상자의 신체적 특성은 <Table 1 과 같다.

Table 1. Characteristics of subjects

\begin{tabular}{ccccc}
\hline Group & Age(yr) & Height(cm) Weight(kg) & BMI \\
\hline \hline $\mathrm{M}(\mathrm{n}=50)$ & $21.9 \pm 2.3$ & $174.2 \pm 5.0$ & $68.2 \pm 6.5$ & $22.5 \pm 1.9$ \\
$\mathrm{~F}(\mathrm{n}=33)$ & $21.8 \pm 2.6$ & $163.3 \pm 5.2$ & $56.8 \pm 6.5$ & $21.3 \pm 2.2$ \\
\hline
\end{tabular}

\section{실험방법}

모든 대상자들은 운동복과 운동화를 착용하고, 준 비운동 없이 $\mathrm{FMS}$ 를 측정하였다. 검사는 7 가지 항목 
으로 Cook et al.(1998)에서 제시하는 구두 교육 자료
를 기반으로 대상자들을 교육 및 검사를 실시하였다.
검사의 목적, 실행방법, 효과는 <Table $2>$ 와 같다. 각
각의 항목은 3 번의 동작을 실시하고, 가장 높은 점수
를 기록하였다. 검사는 FMS를 1 년 이상 사용해온

검사자가 측정하였다.

FMS 점수

Table 2. FMS test method

Purpose

FMS 점수는 4 가지 단계로 구성된다. 점수는 0 점에

DS DS is used to assess bilateral, Stand tall with your feet approximately shoulder width Limited mobility indicates symmetrical, functional mobility apart and toes pointing forward. Grasp the dowel in possible poor glenohumeral of the hips, knees, and ankles. both hands and place it horizontally on top of your head or thoracic spine mobility The dowel held overhead so your shoulders and elbows are at 90 degrees. Press the and poor dorsiflexion of assesses bilateral, symmetrical dowel so that it is directly above your head. While the ankles or poor flexion mobility of the shoulders as maintaining an upright torso, and keeping your heels and in the knee or hip. well as the thoracic spine. the dowel in position, descend as deep as possible.

HS The hurdle step assesses Stand tall with your feet together and toes touching the Poor mobility of the step bilateral functional mobility test kit. Grasp the dowel with both hands and place it leg or poor stability of and stability of the hips, behind your neck and across the shoulders. While the plant leg can knees, and ankles. maintaining an upright posture, raise the right leg and contribute to problems. step over the hurdle, making sure to raise the foot This test requires relative towards the shin and maintaining foot alignment with the bilateral, asymmetric hip ankle, knee and hip. Touch the floor with the heel and mobility, and dynamic return to the starting position while maintaining foot stability. alignment with the ankle, knee and hip.

IL The in-line lunge attempts to Place the dowel along the spine so it touches the back of Problems executing the place the body in a position your head, your upper back and the middle of the movement can be due that will focus on the stresses buttocks. Step onto the $2 \times 6$ with a flat right foot and your to ankle, knee, thoracic as simulated during toe on the zero mark. The left heel should be placed tibial spine, and hip mobility rotational, decelerating, and measurement marker. Maintaining an upright posture so issues and dynamic lateral type movements. the dowel stays in contact with your head, upper back stability problems. and top of the buttocks, descend into a lunge position so the right knee touches the $2 \times 6$ behind your left heel.

SM The shoulder mobility screen Make a fist so your fingers are around your thumbs. In A scapulothoracic dysfunction assesses bilateral shoulder one motion, place the right fist over head and down your may result in decreased range of motion back as far as possible while simultaneously taking your glenohumeral mobility. left fist up your back as far as possible.

ASLR The active straight leg raise tests Lay flat with the back of your knees against the $2 \times 6$ with Poor functional hamstring the ability to dis-associate the your toes pointing up. Place both arms next to your body flexibility may prevent good lower extremity from the trunk with the palms facing up. Pull the toes of your right foot movement in the hip. while maintaining stability in the toward your shin. With the right leg remaining straight torso. and the back of your left knee maintaining contact with the $2 \times 6$, raise your right foot as high as possible.

PU The trunk stability push-up tests Lie face down with your arms extended overhead and Limited performance can the ability to stabilize the spine your hands shoulder width apart. Pull your thumbs down be attributed to poor reflex in an anterior and posterior in line with the (forehead for men, chin for women). With stabilization of the core, plane during a closed-chain your legs together, pull your toes toward the shins and compromised upper-body upper body movement. lift your knees and elbows off the ground. While strength maintaining a rigid torso, push your body as one unit into a pushup position.

RS The rotary stability test Get on your hands and knees over the $2 \times 6$ so your hands Poor reflex stabilization assesses multi-plane trunk are under your shoulders and your knees are under your and compromised scapular stability during a combined hips. The thumbs, knees and toes must contact the sides and hip stability can cause upper and lower extremity of the $2 \times 6$, and the toes must be pulled toward the shins. limited performance. motion. At the same time, reach your right hand forward and right leg backward, like you are flying. Then without touching down, touch your right elbow to your right knee directly over the $2 \times 6$. 
Table 3. FMS mean score for males $(\mathrm{N}=50)$ and female $(\mathrm{N}=33)$

\begin{tabular}{|c|c|c|c|c|c|c|c|c|}
\hline & DS & $\mathrm{HS}$ & IL & $\mathrm{SM}$ & ASLR & PU & $\mathrm{RS}$ & Total \\
\hline Male & $2.1 \pm 0.8$ & $2.08 \pm 0.6$ & $2.22 \pm 0.6$ & $2.52 \pm 0.7$ & $2.32 \pm 0.7$ & $2.04 \pm 0.9$ & $2.10 \pm 0.5$ & $15.38 \pm 2.4$ \\
\hline Female & $2.0 \pm 0.8$ & $2.09 \pm 0.6$ & $2.15 \pm 0.6$ & $2.87 \pm 0.3$ & $2.79 \pm 0.5$ & $1.27 \pm 0.7$ & $2.03 \pm 0.6$ & $15.21 \pm 2.2$ \\
\hline
\end{tabular}

DS: deep squat, HS: hurdle step, IL: in-line lunge, SM: shoulder mobility, ASLR: active straight leg raise, PU: trunk stability push-up, RS: rotary stability

서 3점까지 이며, 3점이 최고점수 이다. 0점은 검사를 진행하는 동안 통증이 발생하였을 때에 주어진다. 1점 은 움직임 패턴을 완전하게 수행할 수 없거나 자세를 유지할 수 없을 때 주어진다. 2점은 움직임을 완전하 게 수행할 수 있으나, 보상적인 움직임이 발견될 때 주어진다. 3점은 보상작용 없이 정확하게 수행하면 주 어진다. 7 가지 항목 중 5 항목은(HS, IL, SM, ASLR, and RS) FMS 점수가 왼쪽과 오른쪽에 각각 주어지 고, 각각의 점수가 다르게 나왔다면 낮은 점수를 기록 한다. 이 낮은 점수를 총점에 합산한다. 예를 들면, IL 을 실시할 때 왼쪽은 2점, 오른쪽은 3점이 나왔다면 총점에는 낮은 점수인 2점을 합산한다.

확인검사(Clearing test)는 impingement clearing exam, press-up clearing exam, and posterior rocking clearing exam 으로 구성되며, $\mathrm{SM}, \mathrm{PU}, \mathrm{RS}$ 각각 검사 후 통증이 발생할 때 실시한다. 확인검사는 오직 통증의 유무만을 평가하고, 만약 확인검사에서 통증이 발생한다면 0점이 주어진다. 7 가지 검사에서 총합 최고점은 21점이다.

\section{자료처리방법}

이 연구는 SPSS 18.0 을 이용하여 종속변인의 평균 및 표준편차를 구하였으며, 성별의 차이를 보고자 Mann-Whitney U test를 실시하였다. 이 연구의 통계 학적 유의 수준은 .05로 설정하였다.

\section{결과}

Table 4. Mann-Whitney U test result of FMS score

\begin{tabular}{ccccccccc}
\hline 변인 & DS & HS & IL & SM & ASLR & PU & RS & Total \\
\hline \hline M Mean Rank & 43.15 & 41.90 & 43.10 & 37.53 & 35.94 & 49.54 & 42.95 & 42.92 \\
F Mean Rank & 40.26 & 42.15 & 40.33 & 48.77 & 51.18 & 30.58 & 40.56 & 40.61 \\
Z & -.569 & -.054 & -.585 & -2.659 & -3.248 & -3.950 & -.541 & -.433 \\
P & .569 & .957 & .559 & $.008^{*}$ & $.001^{*}$ & $.000^{*}$ & .588 & .665 \\
\hline
\end{tabular}

${ }^{*} p \times 05$, DS: deep squat, HS: hurdle step, IL: in-line lunge, SM: shoulder mobility, ASLR: active straight leg raise, PU: trunk stability push-up, RS: rotary stability 
때문에 운동손상의 위험성이 높을 것으로 사료된다. 한편 PU 동작을 통하여 미루어 볼 때 체간 특히, 척 추의 안정성은 여성이 남성보다 취약해 보이기 때문 에 척추 손상의 위험성이 더 높을 수 있다고 예측된 다. 그러므로 이 부분의 보강 운동 프로그램이 필요하 다 할 것이다.

이 연구에 있어서 SM와 ASLR항목에서 여성이 남 성 보다 점수가 더 높았다. ASLR는 몸통의 안정성이 유지되는 동안 하지를 몸통에서 분리시키는 능력을 평가하는 검사이며, 능동적 넙다리뒤근육(hamstring muscle)과 장딴지근 - 가자미근(gastroc - soleus)의 유 연성을 평가할 수 있는 동작이다(Cook et al., 2006b). 넙다리뒤근육(hamstring muscle)의 유연성은 남성 보 다 여성이 더 유연하며(Youdas et al., 2005), 어깨의 가동성을 반영하는 $\mathrm{SM}$ 에서도 여성이 남성보다 점수 가 더 높다는 것을 볼 때와 동일하게 여성은 유연성 과 관련 있는 항목에서 남성 보다 더 높은 기능적 움 직임을 가지고 있다고 생각된다.

18 세에서 40 세 사이 활동적인 성인을 대상으로 한 Schneiders et al.(2011)의 선행연구에서도 여성은 가동 성과 관련 있는 $\mathrm{SM}, \mathrm{ASLR}$ 에서 더 높은 점수를 받았 고, 남성은 안정성과 관련 있는 $\mathrm{PU}, \mathrm{RS}$ 의 기능적 움 직임이 여성 보다 더 높았다. 그러나 삼면(multi-plane) 에서 골반, 몸통의 안정성을 동시에 평가할 수 있는 $\mathrm{RS}$ 항목에서는 이 연구와 다른 결과가 나타났는데, 그 이유는 Schneiders et al.(2011)의 연구에서는 규칙적인 특정 훈련에 따른 운동생리학적 측면의 적응에 따른 결과이고, 이 연구에서는 규칙적인 운동을 하지 않았 기 때문으로 사료된다.

손상과 관련된 선행연구를 살펴보면, 여성은 스포츠 손상에 있어서 허리부상 혹은 목 부상이 남성에 비하 여 높게 나타났는데, 이는 남성에 비하여 낮은 안정성 과 근력에 기인했을 수 있다(Sallis et al., 2001; Knapik et al., 2001; Zelisko et al., 1982). Butler et al.(2009)의 연구에서는 DS, IL, SM, ASLR 항목에서 여학생이 남학생보다 점수가 더 높게 나타났다. 이와 같은 결과가 도출된 이유는 대상자가 사춘기 중학생으 로 성장과정이며, 여성의 신체적 발달이 남학생에 비 해 정점에 도달하는 시기 때문으로 생각된다. 뿐만 아 니라 DS 및 IL는 발목, 무릎, 어깨 및 척추의 가동성
과 안정성을 동시에 평가하는 항목이며, $\mathrm{SM}$ 와 ASLR 또한 가동범위를 평가하는 항목이므로 남학생보다 더 유연한 여학생들이 수행에 있어서 더 유리한 부분이 있었을 것으로 생각된다(Kibler et al., 1989). 중학생을 대상으로 한 스포츠손상 연구에서는 오히려 여학생이 남학생보다 스포츠 손상이 더 높은 것으로 보고되었다 (Chau et al., 2007). 그러므로 중학생에 있어서 FMS만 으로 스포츠손상을 예측하는 부분에서 더 검증할 필요 가 있고, Lisman et al.(2013)의 연구와 같이 유산소능 력 측정을 비롯한 다른 체력요인을 동시에 평가하는 추가적인 연구도 고려할 필요성이 있다고 사료된다.

상기 연구를 종합해 볼 때 여성은 남성에 비해서 유연성은 뛰어나지만, 근력 및 안정성 부분에서 움직 임의 질이 취약하므로 스포츠나 운동프로그램을 적용 하기 이전에 이러한 부분을 보완한다면 운동손상예방 에 도움이 될 것으로 생각된다.

이 연구에서 남성이 여성보다 높은 점수를 받은 $\mathrm{PU}$ 은 상체의 닫힌 사슬 운동(closed kinetic chain) 동 안 시상 면에서의 몸통 안정성을 평가하는 검사이다 (Cook et al., 2006b). Schneiders et al.(2011)의 연구에 서도 동일하게 PU항목에서 남성이 여성보다 높게 나 타났다. PU은 상체의 근력과 동시에 몸통의 안정성을 요구하는 만큼 Kibler et al.(1989)의 연구와 동일하게 남성이 여성에 비해서 상체와 몸통근력과 관련된 움 직임이 우월하다고 할 수 있겠다. Schneiders et al.(2011)의 연구도 남성이 안정성과 근력을 보는 항목 에서 여성보다 더 높은 점수가 나타났으나, 이러한 부 분은 훈련 과정에서 성별 근육량에 따른 차이로 사료 된다. 이 연구에서는 RS항목에서 남성과 여성이 유의 한 차이가 나타나지 않았다. 평균점수는 남성이 $2.10 \pm 0.5$, 여성이 $2.03 \pm 0.6$ 으로 3점을 받은 대상자는 극히 드물었기 때문으로 생각된다. Schneiders et al.(2011)의 연구에서도 RS항목에서 최고점수인 3점을 받은 대상자들은 소수였으며, 사관후보생을 대상으로 한 선행연구(O'connor et al., 2011)에서도 RS 항목에 서 3점을 받은 대상자는 매우 적었다. 그 이유는 FMS 검사는 엘리트 운동선수들의 기능적인 움직임을 평가 하기 위해서 개발된 만큼 규칙적인 운동을 하지 않는 일반인에게 적용하기에는 제한점이 있는 것으로 사료 되며, 차후에 규칙적으로 운동을 하지 않는 일반인들 
을 위한 평가방법이 더 연구되어야 할 것이다.

유사한 연령대를 대상으로 진행된 손상과 성차를 비교한 선행연구에서는 남성들이 어깨와 넙다리 손상 이 여성보다 많은데 FMS 항목에서 어깨와 넙다리 유 연성과 관련 있는 $\mathrm{SM}$ 와 $\mathrm{ASLR}$ 점수가 남성이 더 낮 은 것과 관련이 있을 가능성이 있어 보인다(Sallis et al., 2001; Zelisko et al., 1982). 그러므로 스포츠 손상 을 예방하기 위해서 남성은 여성에 비해 취약한 상지 와 하지의 유연성을 보강하여야 할 것으로 사료된다.

FMS동작과 손상부위별 연관성을 밝히려는 연구가 있었다(Woo et al., 2014). 그러나 FMS는 근력, 유연 성, 가동범위( $\mathrm{ROM})$, 협응력, 평형성 그리고 고유수용 감각을 통합적으로 평가하는 시스템이기 때문에 손상 부위와 FMS 동작을 직접적으로 비교하는 것은 무리 가 있다(Cook et al., 2006)고 판단된다. Woo et al.(2014)도 야구선수에 있어서 FMS와 손상간의 연관 성에 제한점이 있다고 밝히고 있으며, 차후에 스포츠 종목과 더 상관성 있는 FMS 항목을 선별하는 연구가 더 진행되어야 할 것으로 사료된다.

이 연구에서 FMS 총점은 남녀차이가 유의하게 나 타나지 않았다. 선행연구인 Schneiders et al.(2011)의 연구에서도 남녀의 총점 차이는 유의하게 나타나지 않 았다. 미식축구선수, 군인 및 소방관 등을 대상으로 실 시한 연구에서 총점이 14점 이하일 경우 더 높은 손 상에 노출되었고, 특히 선행연구에서 14점 이하의 선 수는 15점 이상인 선수보다 손상에 대한 노출이 11배 높고, 좌우 불균형이 있는 선수들도 그렇지 않은 선수 들에 비해 3배나 손상 위험이 높았다(Kiesel et al., 2007; Kiesel et al., 2008; Lisman et al., 2013)고 하였 다. 그러나 14 점 이하 이더라도 낮은 점수의 항목과 관련하여 개인화된 운동프로그램을 적용한다면 FMS 점수가 개선 될 수 있고, 나아가 활동적인 스포츠 참 여에 있어서 손상의 위험을 줄일 수 있다(Kiesel et al., 2011)는 보고는 고무적이다. 또한 소방관을 대상으로 한 연구에서는 배가로근(transversus abdominis) 교육 을 포함한 체간 안정성 트레이닝 프로그램으로서 손상 발생률을 대조군에 비해서 $44 \%$ 감소시켰다고 보고하 였다(Peate et al., 2007). 반면에 소방관을 대상으로 한 다른 연구에서는 기능적 움직임의 질을 개선하기 위해 3 개월 동안 운동프로그램을 적용시켰으나 총점의 유의
한 변화는 나타나지 않았다(Frost et al., 2012)고 하였 다. 이러한 결과가 나타난 이유는 Kiesel et al.(2011)의 연구와 다르게 Frost et al.(2012)의 연구는 대상자들에 게 개별화된 운동프로그램을 적용하지 않았고, 서로 다른 대상자들로 인한 결과가 나타난 것으로 생각된 다. 따라서 대상자들에 따른 교정 운동프로그램의 효 과를 더 검증해야 하고, 더 효과적인 운동프로그램 개 발 연구가 있어야 할 것이다.

실제로 운동선수나 일반인들이 수준 높은 활동들을 할 경우 이러한 근본적인 움직임이 결여되어 있으며, 활동을 하는 동안 보상적인 움직임에 의존하게 된다. 이러한 보상작용이 지속될 경우 크거나 작은 손상에 노출 될 수 있다(Cook et al., 2006a). 스포츠 참여로 인한 부상예방과 체력 향상을 위해서 운동프로그램을 적용한다면 기능적 움직임 평가를 참고하는 것이 바 람직하다고 할 수 있겠다.

\section{결론}

20대의 남성과 여성은 기능적 움직임의 질적 차이 가 나타났다. 여성은 SM, ASLR 에서 남성보다 더 기 능적 움직임의 질이 높았고, 남성은 PU에서 여성보다 더 기능적 움직임의 질이 높았다. 따라서 기능적 움직 임의 질을 증진시키거나 활동적인 스포츠를 참여하기 전 남성은 부족한 유연성을 보완하고, 여성은 상체근 력과 몸통의 안정성을 고려해서 운동프로그램을 적용 시켜야 할 것이다.

\section{참고문헌}

An, K. O., Oak, J. S., Park, W. Y., Kim, J. G., \& Yang, S. J. (2013). Gender Differences in the Effect of Rehabilitive Exercise Program during 24weeks after Anterior Cruciate Ligament Reconstruction. Korean Journal of Sport Science, 24(2): 195-203.

An, S. H., \& Lee, J. H. (2010). Reliability and Validity 
of the Korean Version of the Functional Movement Screen. The Jaurnal Korean Society of Physical Therapy, 22(5): 83-93.

Anstee, L, Docherty, C., Gansneder, B., \& Shultz, S. (2003). Inter-tester and intra-tester reliability of the functional movement screen paper presented at: National athletic training association national convention, st. Louis, MO.

Backous, D. D., Friedl, K. E., Smith, N. J., Parr, T. J., \& Carpine, W. D. Jr. (1988). Soccer injuries and their relation to physical maturity. American Journal of Diseases of Children, 142(8): 839-842.

Batt, M. E., Jaques, R., \& Stone, M. (2004). Preparticipation examination (screening): Practical issues as determined by sport: A united kingdom perspective. Cinical Journal of Sport Medicine, 14(3): 178-182.

Baumhauer, J. F., Alosa, D. M, Renstrom, A. F., Trevino, S., \& Beynnon, B. (1995). A prospective study of ankle injury risk factors. The American Jaurnal of Sports Medicine, 23(5): 564-570.

Beachy, G., Akau, C. K., Martinson, M., \& Olderr, T. F. (1997). High school sports injuries. A longitudinal study at punahou school: 1988 to 1996. The American Journal of Sports Medicine, 25(5): 675-681.

Bell, N. S., Mangione, T. W., Hemenway, D., Amoroso, P. J., \& Jones, B. H. (2000). High injury rates among female army trainees: A function of gender? American Jaurnal of Preventive Medicine, 18(3): 141-146.

Butler, R. J., Elkins, B., Kiesel, K. B., \& Plisky, P. J. (2009). Gender differences in functional movement screen and Y-balance test scores in middle school aged children. Medicine \& Science in Sports \& Exercise, 41(5): 183.

Chandy, T. A., \& Grana, W. A. (1985). Secondary school athletic injury in boys and girls: A three-year comparison. Physician Sports medicine, 13(3): 106-111.

Charlton, W. P. H., St. John, T. A, Ciccotti, M. G., Harrison, N., \& Schweitzer, M. (2002). Differences in the femoral notch anatomy between men and women a magnetic resonance imaging study. American Journal of Sports Medicine, 30: 329-333

Chau, N., Pre'dine, R., Aptel, E., Houtaud, A, \& Choquet M. (2007). School injury and gender differentials: a prospective cohort study. European Journal of Epidemidogy, 22(5): 327-334

Cook, G., Burton, L., \& Hoogenboom, B. (2006a). Pre-participation screening. the use of fundamental movements as an assessment of function - part 1. North American Journal of Sports Physical Therapy, 1(2): 62-72.

Cook, G., Burton, L., \& Hoogenboom, B. (2006b). Pre-participation screening: the use of fundamental movements as an assessment of function - part 2. North American Journal of Sports Physical Therapy, 1(3): 132-139.

Cook, G., Burton, L., Fields, K., \& Kiesel, K. (1998). The functional movement screen. Danville, VA: Athletic Testing Services, Inc.

Frost, D. M., Beach, T. A, Callaghan, J. P., \& McGill, S. M. (2012). Using the functional movement screen to evaluate the effectiveness of training. Journal of Strength and Conditioning Research / National Strength \& Conditioning Association, 26(6): 1620-1630.

Gwinn, D. E., Wilckens, J. H, McDevitt, E. R., Ross, G., \& Kao, T. C. (2000). The relative incidence of anterior cruciate ligament injury in men and women at the united states naval academy. The American Journal of Sports Medicine, 28(1): 98-102.

Hewett, T. E., Lindenfeld, T. N., Riccobene, J. V., \& Noyes, F. R. (1999). The effects of 
neuromuscular training on the incidence of knee injury in female athletes. American Journal of Sports Medicine, 27: 699-705.

Hickey, J. N., Barrett, B. A., Butler, R. J., Kiesel, K. B., \& Plisky, P. J. (2010). Reliability of the functional movement screen using a 100-point grading scale: 1765: Board \#202 june 2 2:00 PM - 3:30 PM. Medicine \& Science in Sparts \& Exercise, 42(5): 392.

Kibler, W. B., Chandler, T. J., Uhl, T., \& Maddux, R. E (1989). A musculoskeletal approach to the preparticipation physical examination preventing injury and improving performance. The Anerican Jaumal of Sports Medaine, 17(4): 525-531.

Kiesel, K B., Plisky, P. J., \& Butler, R J. (2011). Functional movement test scores improve following a standardized off-season intervention program in professional football players. Scandinavian Journal of medicine \& science in Sparts, 21(2): 287-292.

Kiesel, K. B., Plisky, P. J., \& Voight, M. L. (2007). Can serious injury in professional football be predicted by a preseason functional movement screen? North American Journal of Sports Physical Therapy, 2(3): 147-158.

Kiesel, K., Plisky, P., \& Kersey, P. (2008). Functional movement test score as a predictor of time-loss during a professional football team's pre-season. Medicine \& Science in Sports \& Exercise, 40(5): S234.

Kim, S. W., Kim, K H, Lee, C. M., Choi, D. H, Jung, I. G., Kim, K. J., Choi, J. I., Kang, Y. S., Yang, J. H., Choi, J. H., Ku, K. S., \& Park, T. S. (2007). Growth and Development studies. Seoul; Deahan Media.

Knapik, J. J., Sharp, M. A., Canham-Chervak, M, Hauret, K., Patton, J. F., \& Jones, B. H. (2001). Risk factors for training-related injuries among men and women in basic combat training. Medicine and Science in
Sports and Exercise, 33(6): 946-954.

Lindenfeld, T. N., Schmitt, D. J., Hendy, M. P., Mangine, R. E., \& Noyes, F. R. (1994). Incidence of injury in indoor soccer. The American Journal of Sports Medicine, 22(3): 364-371.

Lisman, P., O'connor, F. G., Deuster, P. A., \& Knapik, J. J. (2013). Functional movement screen and aerobic fitness predict injuries in military training. Medicine \& Science in Sports \& Exercise, 45(4): 636-643.

Livingston, L. A., \& Gahagan, J. C. (2001). The wider gynaecoid pelvis-larger $\mathrm{Q}$ angle-greater predisposition to ACL injury relationship: Myth or reality? Clinical Biomechanics, 16: 951-952.

Messina, D. F., Farney, W. C., \& DeLee, J. C. (1999). The incidence of injury in texas high school basketball. A prospective study among male and female athletes. The American Journal of Sports Medicine, 27(3): 294-299.

Minick, K., Kiesel, K., Burton, L., Taylor, A, Plisky, P., \& Butler, R. (2010). Interrater reliability of the functional movement screen. Journal of Strength and Conditioning Research, 24(2): 479-486.

Mottram, S., \& Comerford, M. (2008). A new perspective on risk assessment. Physical Therapy in Sport, 9(1): 40-51.

Myklebust, G., Maehlum, S., Holm, I., \& Bahr, R. (1998). A prospective cohort study of anterior cruciate ligament injuries in elite norwegian team handball. Scandinavian Journal of Medicine \& Science in Sports, 8(3): 149-153.

O'connor, F. G., Deuster, P. A, Davis, J., Pappas, C. G., \& Knapik, J. J. (2011). Functional movement screening: Predicting injuries in officer candidates. Medicine \& Science in Sports \& Exercise, 43(12): 2224-2230. 
Onate, J. A., Dewey, T., Kollock, R. O., Thomas, K. S., Van Lunen, B. L., DeMaio, M., et al. (2012). Real-time intersession and interrater reliability of the functional movement screen. Journal of Strength and Conditioning Research / National Strength \& Conditioning Association, 26(2): 408-415.

Parenteau-G, E., Gaudreault, N., Chambers, S., Boisvert, C., Grenier, A., Gagné, G., (2014). Functional movement screen test: A reliable screening test for young elite ice hockey players. Physical Therapy in Sport, 15(3): 169-175.

Peate, W., Bates, G., Lunda, K., Francis, S., \& Bellamy, K. (2007). Core strength: A new model for injury prediction and prevention. Journal of Occupational Medicine and Toxicdogy, 2(3): 1-9.

Sallis, R., Jones, K., Sunshine, S., Smith, G., \& Simon, L. (2001). Comparing sports injuries in men and women. International Journal of Sports Medicine, 22(06): 420-423.

Schneiders , A. G., Davidsson, Ă, Hörman, E., \& Sullivan, S. J. (2011). Functional movement screen normative values in a young, active population. The International Journal of Sports
Physical Therapy, 6(2): 75-82.

Stevenson, M. R., Hamer, P., Finch, C. F., Elliot, B., \& Kresnow, M. (2000). Sport, age, and sex specific incidence of sports injuries in western australia. British Journal of Sparts Medicine, 34(3): 188-194.

Wiesler, E. R., Hunter, D. M, Martin, D. F., Curl, W. W., \& Hoen, H. (1996). Ankle flexibility and injury patterns in dancers. The American Journal of Sports Medicine, 24(6): $754-757$.

Woo, S. S., Kim, J. Y., Kim, L. N., So, W. Y., \& Song, H. S. (2014). The Relationship between High-school Baseball Players' Injury and Functional Movement Screen. Coaching Developments, 16(1): 189-197.

Youdas, J. W., Krause, D. A., Hollman, J. H., Harmsen, W. S., \& Laskowski, E. (2005). The influence of gender and age on hamstring muscle length in healthy adults. Journal of Orthopaedic \& Sports Physical Therapy, 35(4): 246-252.

Zelisko, J. A., Noble, H. B., \& Porter, M. (1982). A comparison of men's and women's professional basketball injuries. The American Journal of Sports Medicine, 10(5): 297-299. 
